\title{
ANTI-CORRUPTION ELEMENTS IN THE GHANAIAN PUBLIC PROCUREMENT LAW
}

\author{
Annika Engelbert
}

\section{(2015) 2 APPLJ 29}

\begin{abstract}
Corruption in public procurement is widespread and particularly damaging to development objectives, as it undermines any state's duty to maximize the social and economic welfare of its citizens. Despite this, research on country-specific institutional arrangements meant to address this problem has remained scarce. This paper aims to fill this gap by analyzing particular anti-corruption components of the Ghanaian procurement system, and by discussing to what extent they are suitable to form a strong corruption deterrence mechanism. The study identifies three clusters of anti-corruption tools: (1) preventive measures: choice of tender method, publication of tender data, record keeping, and contract management; (2) enforcement mechanisms: compliance checks, audits, and review systems; and (3) scope and limitation of sanctions. In view of an envisaged legislative reform of the Ghanaian public procurement system, several recommendations can be drawn from the analysis. These are, in particular: adjusting the thresholds for procurement methods; facilitating access to tender information; integrating contract management provisions; building capacity in audit institutions; strengthening the administrative review system; and formalizing collaboration between the Public Procurement Authority and law enforcement organs. Based on national legislation and empirical data from World Bank reports and the Ghanaian Public Procurement Authority, the analysis also takes into account findings from expert interviews conducted with representatives of procurement authorities, the business community, and donor organizations in Accra in November 2014.
\end{abstract}




\section{ANTI-CORRUPTION ELEMENTS IN THE GHANAIAN PUBLIC PROCUREMENT LAW}

Annika Engelbert ${ }^{*}$

MA

Research associate, Ruhr University Bochum

\section{Introduction}

The recently published Corruption Perceptions Index 2014 by Transparency International - despite all its shortcomings as a measurement tool - has once again confirmed that developing countries are more affected by corruption than other states. ${ }^{1}$ Since the introduction of the concept of 'good governance' by international financial institutions, both donors and partner countries have put considerable effort into fighting corruption and its detrimental impact on social and economic development. ${ }^{2}$ Procurement, ${ }^{3}$ as one of the core activities in public administration, has been in the center of these endeavors as it represents the largest share of government expenditure. ${ }^{4}$ Corruption in public procurement undermines the quality of government services because it "increases public spending without an increase in public welfare" ${ }^{25}$, and is therefore particularly damaging for developing countries. First and foremost, corruption causes important losses of scarce financial resources that are required to cover basic needs of a developing state's population. Secondly, corruption favors the misallocation of public funds. Governments in highly corrupt environments tend to invest in projects where opportunities to obtain kickbacks and

\footnotetext{
"The author would like to thank Fred Borson, University of Nottingham, and Dr. Nina-Annette ReitBorn, Ruhr University Bochum, for their valuable comments on this paper.

${ }^{1}$ The Corruption Perceptions Index (CPI) is based on expert reports and assigns a score on a scale from 0 (highly corrupt) to 100 (very clean) to each country. Findings of the latest CPI reveal that $92 \%$ of all Sub-Saharan African countries score below 50 with an average of 33; the global average score is 43 . In the EU and Western Europe, only $16 \%$ of all countries score below 50 . Transparency International 2014: http://www.transparency.org/cpi2014/results. On the correlation between corruption and development see also Aidt 2011; Andvig et al. 2000: 6, 53-54; Bayley 1989: 935; Khan 2006: 216; Ofosu-Amaah et al. 1999: 1; Szeftel 2000: 427.

${ }_{2}^{2}$ Cf. Art 33 Busan Partnership for Effective Development Co-operation of 2011.

${ }^{3}$ Governments need to acquire goods, construction works and services by any contractual means (purchasing, hiring, or other) in order to perform their functions. Such acquisition is effected with resources from public funds, aiming to achieve best value for money.

${ }^{4}$ Cf. Akech 2006:831.

${ }^{5}$ Williams-Elegbe 2012:12.
} 
bribes are good, and neglect other procurement needs that are less prone to corruption. Capital-intensive procurement like large infrastructure projects or defense is given priority over investments in areas such as education and health, which are of utmost importance for development. ${ }^{6}$ Thirdly, corruption in procurement not only means that goods or services will be purchased at higher prices, but also of lower quality. Inadequate quality standards of basic government provisions such as water supply or building security can cause immediate physical threats to the population. ${ }^{7}$

Taking these harmful effects into account, Ghana has strong incentives to foster anticorruption elements in its public procurement system. Despite its relatively moderate corruption level compared to other Sub-Saharan African states, one cannot deny that Ghana is highly affected by corruption, ${ }^{8}$ while a considerable percentage of the annual domestic budget is spent through public procurement. ${ }^{9}$ The Public Procurement $\mathrm{Act}^{10}$ (PPA-G) - which is still in place today - is the result of a major reform process in the late 1990s, and is based on the UNCITRAL Model Law on Procurement of Goods, Construction and Services (1994). After ten years of implementation, the PPA-G is currently being subjected to a legislative reform process, offering the opportunity to reflect on strengths and weaknesses of the regulatory framework with special regard to its anti-corruption capacity, in order to make it more compliant with newest international developments and more responsive to challenges arising from corruption.

While research on corruption in public procurement is growing, ${ }^{11}$ studies on individual public procurement systems and their abilities to curb corruption remain scarce. This paper seeks to identify particular anti-corruption components of the Ghanaian procurement system, and to discuss whether they are suitable to form a strong corruption deterrence mechanism. The following section will focus on

\footnotetext{
${ }^{6}$ Andvig et al. 2000: 97; Heggstad \& Frøystad 2011: 6; Lambsdorff 2006: 31-32; Mauro \& Driscoll 1997; Moody-Stuart 1997: 22-23; Søreide 2002: 6; Transparency International 2006: 28.

${ }^{7} \mathrm{Cf}$. Williams-Elegbe 2012: 12-13.

${ }^{8}$ Ghana ranks $8^{\text {th }}$ out of all Sub-Saharan African countries, and 61 out of 175 countries in total (score 48) in the CPI 2014; Transparency International 2014: http://www.transparency.org/cpi2014/results. In the Worldwide Governance Indicators 2013, Ghana reaches a percentile rank of 56 for the Control of Corruption indicator; The World Bank Group 2014: http://info.worldbank.org/governance/wgi/index.aspx\#home.

${ }^{9}$ Cf. Akech 2006: 831.

${ }^{10}$ The Public Procurement Act (Act 663) of 2003 (Ghana).

${ }^{11}$ E.g. Piga 2011, Søreide 2002, Transparency International 2006, Ware et al. 2011, Williams-Elegbe 2012.
} 
preventive measures that are meant to foster transparency, competition and objective criteria in public procurement, namely the choice of tender method, the publication of tender data, record keeping and contract management. Enforcement mechanisms enshrined in public procurement law, in particular compliance checks, audits, and review systems, will be analysed in the third section. The fourth section will discuss scope and limitations of sanctioning corruption in public procurement. In the final section, recommendations will be proposed to further improve the regulatory framework on public procurement with regard to anti-corruption.

Notwithstanding theoretical considerations, the analysis is based on findings from expert interviews conducted with representatives of procurement authorities, the business community, and donor organizations in Accra, in November 2014. Drawing from focus topics that were identified during the interviews, the PPA-G and empirical data of three World Bank reports from 2003, 2007 and 2010, as well as the latest annual report (2011) of the Ghanaian Public Procurement Authority were assessed. Wherever appropriate, reference will be made to public procurement systems in East Africa.

\section{Preventive measures to strengthen transparency, competition and objective criteria in public procurement}

The institutional setup of public procurement provides for a number of measures that are meant to prevent corruption. ${ }^{12}$ Relevant legal norms and organizations aim to motivate individuals to act lawfully by creating negative incentives. It is assumed that a high probability of getting caught and severe consequences for unlawful actions will have a deterrent effect on bidders and procurement officers, and their willingness of being involved with corrupt transactions. Accordingly, the anti-corruption effect of procurement law will unfold only when deterrence is greater than the enticement of personal enrichment. The probability of getting caught (or the 'risk of detection') is closely linked to the principles of "transparency, competition, and objective criteria in

\footnotetext{
${ }^{12}$ These can be precautionary or substantial measures. Precautionary, i.e. rather indirect strategies focus on awareness rising, clear and applicable procurement laws and regulations, capacity building of procurement officers, and trainings on ethics and integrity - to only name a few. These shall not be subject of this study though. Instead, this paper will concentrate on concrete anti-corruption measures prescribed in procurement laws.
} 
decision-making, that are effective, inter alia, in preventing corruption"13. The following will discuss these core principles, which are integral parts of any modern public procurement system and that have been translated into procurement procedures prescribed by Ghanaian law.

\subsection{Choice of tender method}

Open tendering is internationally recognized as the default method used in public procurement ${ }^{14}$ as it allows for the largest degree of competition and enhances transparency. Alternative methods can only be applied under specific and prescribed circumstances. It is assumed that wide competition generates value for money, i.e. the best price and quality for goods, works, or services can be achieved by inviting the maximum number of eligible bidders to tender. In order to attract as many bidders as possible, procurement notices are to be published in an adequate format, e.g. in national newspapers or in an online medium in a language that is spoken by the majority of the population. Nevertheless, not every tender procedure needs to be open, as the effort it takes must be put in relation to the contract value. Open tendering requires a considerable resource investment by the procuring entities in terms of time, costs, and manpower. This is certainly justifiable for important contract amounts or technically demanding subject matters, whereas less expensive projects or off-the-shelf products can be procured through simplified procedures. In order to define which tender method to be used, public procurement law prescribes threshold amounts for restricted tender participation.

In contrast to the rationale of competition by means of open tendering, actors involved in corrupt activities will have a strong interest in distorting competition. They will rather try to restrict the number of bidders to a minimum in order to select the preferred - corrupting - bidder. Hence, the overuse of alternative methods limiting competition instead of opening up tender participation can be an indication for corruption and needs special attention. ${ }^{15}$ Regulatory frameworks often do so by imposing approval by superior procurement authorities for tender methods that are particularly prone to corruption. Bidders disadvantaged by the choice of method

\footnotetext{
${ }^{13}$ Art 9 United Nations Convention against Corruption of 2003.

${ }^{14}$ Cf. Art 28 (1) UNCITRAL Model Law on Public Procurement of 2011.

${ }^{15} \mathrm{Cf}$. Udeh 2013: 189.
} 
need to have the right to request a review in order to ensure competition and to prevent favouritism. ${ }^{16}$ Until recently, however, it was internationally accepted that the choice of the procurement method was not challengeable. ${ }^{17}$ Only with the introduction of the new UNCITRAL Model Law on Public Procurement of 2011, are all procurement matters without exception, subject to review ${ }^{18}$ - a substantial change that will probably be reflected in national procurement laws in the future.

Open tendering has been implemented in the Ghanaian public procurement system, which requires procedures to be conducted as competitive (national or international) tendering, unless certain conditions are met and justified. ${ }^{19}$ Contract volume thresholds are prescribed, to determine whether or not prequalification needs to be included in the selection process, allowing smaller procurement projects to request quotations from a limited number of suppliers instead of fully opening up the tender procedure. ${ }^{20}$ These procurement methods follow a hierarchical logic: The higher the contract volume, the larger the competitive aspect. The applicable thresholds as prescribed in sch 3 of the PPA-G have not been revised since 2003; the amounts have thus not been adapted to new economic conditions such as inflation ${ }^{21}$ and the devaluation of the national currency in 2007. Interviewees have therefore stressed the necessity to define thresholds not in the revised PPA-G, but in the accompanying regulations enacted by the Ministry of Finance in order to make future adaptations more flexible. ${ }^{22}$

As a second option for alternative methods other than open tendering, procuring entities can seek approval from the Public Procurement Authority to conduct restricted tendering or single-source procurement, regardless of the contract value. ${ }^{23}$ According to the annual report 2011 of the Public Procurement Authority, between 400 and 500 requests for each of the two methods were received in one year, and

\footnotetext{
${ }^{16}$ See ch 3.2 .

${ }^{17}$ UNCITRAL Model Law on Procurement of Goods, Construction and Services of 1994; Nicholas 2009: 152-153.

${ }^{18}$ Udeh 2013: 190. Appeals can only be dismissed due to missing the deadline, lack of standing and lack of merit, see Art 67 (6) (a) and (b) UNCITRAL Model Law on Public Procurement of 2011.

${ }^{19}$ Ss 25, 35 (1) and (3) PPA-G.

${ }^{20}$ Sch 3 PPA-G.

${ }^{21}$ The consumer price inflation increased from $11.6 \%$ in June 2013 to reach $13.5 \%$ in December 2013 and $15.0 \%$ in June 2014 (Bank of Ghana,

http://www.bog.gov.gh/index.php?option=com_wrapper\&view=wrapper\&ltemid=263).

${ }_{22}$ Regulations for the current PPA-G had never been enacted, although s 97 (1) PPA-G grants the Ministry the power to do so.

${ }^{23}$ Ss 38, 40 PPA-G.
} 
more than $90 \%$ of the requests were approved. ${ }^{24}$ Restricted tendering may only be applied if a limited number of suppliers or service providers are qualified to perform the contract, or "if the time and cost required to examine and evaluate a large number of tenders is disproportionate to the value of the goods, works or services to be procured." ${ }^{25}$ The second argument on efficiency seems rather unsubstantial as the threshold matrix is supposed to solve this dilemma. The first point on the availability of eligible contractors is more relevant due to the fact that markets in developing countries are often less mature, for instance in highly specialized technical areas. However, knowledge on the specific markets must first be obtained, in order to accurately judge each situation. It would hence be advisable to request procuring entities - or, alternatively, a central procurement institution - to conduct a market research on a regular basis. Single sourcing, on the other hand, can be applied in case of only one suitable supplier or service provider, urgency, catastrophic events, compatibility with existing material, research-related procurement, national security or secondary economic procurement objectives. ${ }^{26}$ Although the special preconditions for single sourcing are well defined by law, procuring entities may distort their procedures to qualify for direct contracting. In this context, it was reported during interviews and confirmed by findings of the Public Procurement Authority that procurement proceedings get artificially delayed to make up an emergency situation and to justify single sourcing. ${ }^{27}$

Even before the PPA-G entered into force, the World Bank had expressed concerns in its Country Procurement Assessment Report 2003 on the overuse of restricted tendering and single sourcing:

"Selective bidding and shopping are widely used to offer contracts to specific contractors. These contractors are the ones campaigning against the public procurement bill." ${ }^{28}$

\footnotetext{
${ }^{24}$ Single source: 481 requests received, 366 approved, 68 conditionally approved, 47 not approved; restricted tendering: 408 requests received, 341 approved, 54 conditionally approved, 13 not approved (The Public Procurement Authority of Ghana 2012: 8).

${ }^{25} \mathrm{~S} 38$ (b) PPA-G.

${ }^{26}$ S 40 PPA-G.

${ }^{27}$ The Public Procurement Authority of Ghana 2012: 22.

${ }^{28}$ World Bank 2003 (Vol 2): 31.
} 
For an analysis of the current use of procurement methods, one needs to take into account both the percentage based on contract amounts and on the total number of tenders (see below table 1). Looking at the methods defined by thresholds (international and national tendering and request for quotations) used in 2011, competitive tendering seemed to be applied as the default method: it covered indeed more than half of the total value of contracts. High-value procurement, however, was not very frequent; the percentage of the use of competitive tendering based on the number of tenders was only $16 \%$. The opposite is the case for requests for quotations: Due to the low contract amounts, its share was much lower based on the contract sizes than on the total number of tenders. Restricted tendering was applied for a very low number of procurement procedures (1.25\%), but these few contracts constituted almost one third of the total contract amounts. It would be interesting to investigate further the reasons for restricted tendering, i.e. either efficiency or specialization. If the first is the case, it may be necessary to adjust the thresholds. Drawing from the numbers provided by the Public Procurement Authority for 2011, the concern that single-source procurement is overused cannot be supported. Both the share in the number and the value of procurement contracts is rather low, namely almost $3 \%$ and $6 \%$. Much more interesting are the numbers of minor value procurement - which is not prescribed by law - and other procedures which have been conducted outside any procurement regulation. They make up a negligible percentage in contract amounts, i.e. those are very small procurement contracts, although their share in the total number of contracts is above $15 \%$. 
Table 1: The use of procurement methods

\begin{tabular}{|c|c|c|}
\hline $\begin{array}{c}\text { Procurement method } \\
\text { tendering }\end{array}$ & $\begin{array}{c}\text { Percentage based on } \\
\text { contract amounts }\end{array}$ & $\begin{array}{c}\text { Percentage based on } \\
\text { number of tenders }\end{array}$ \\
\hline $\begin{array}{c}\text { International competitive } \\
\text { National competitive tendering }\end{array}$ & 5.04 & 0.27 \\
\hline Request for quotations & 7.50 & 15.86 \\
\hline Restricted tendering & 31.40 & 1.25 \\
\hline Single-source procurement & 6.09 & 2.69 \\
\hline Minor value procurement & 0.09 & 7.16 \\
\hline Unprescribed procedures & 0.72 & 8.21 \\
\hline
\end{tabular}

Source: The Public Procurement Authority of Ghana 2012: 13.

Limited participation in tender procedures is not, however, only a matter of choice of the procurement method. Interviews with business associations have revealed that only $30 \%$ of the whole business community actually takes part in tendering. Others have the impression that government contracts are not appropriate for them as they have to fulfil certain requirements above their capacities, e.g. the provision of tender securities or the level of technical standards. This is especially the case for donor funded projects. Furthermore, government contracts are not always attractive for bidders as they have the reputation to have considerable payment delays. Encouraging participation and fostering competition in public procurement would hence be a task for the Government of Ghana. 


\section{$2.2 \quad$ Publication of tender data}

As mentioned above, the choice of procurement method not only defines the range of participation in a tender procedure, but also the degree of external transparency in terms of publication of tender information. Whereas open tendering requires the advertisement of procurement notice in nationwide newspapers or other adequate media, the invitation of bidders to the tender opening session, and the public display of the award notice, information on procurement under alternative methods are typically less accessible for the public - notwithstanding general non-disclosure provisions. The publication of tender information is not a remedy itself to prevent corruption as the possibility to falsify documents persists. Yet, deterrence should not be underestimated: When manipulated documentation is exposed to public monitoring, the risk of detection rises. Hence, the notice of evaluation outcome is of particular importance, as this information is an indispensable precondition to claim a review by bidders. Since they do not have access to all stages of the tender process, their level of information - although high compared to other monitoring bodies as will be discussed below - remains incomplete. In order to be able to judge on appropriate tender conduct, bidders rely on appropriate information concerning their own performance in relation to the results achieved by other tenderers.

Provisions in the PPA-G that regulate the publication of tender information would need amendments in certain parts. Whereas tender advertisements ${ }^{29}$ and opening sessions ${ }^{30}$ are to be conducted according to international standards, the manner in which contract awards notices are to be published is not specified in the Act, but referred to the regulations that have never been enacted. ${ }^{31}$ It would be advisable instead to include provisions on the publication of award notices according to UNCITRAL standards. ${ }^{32}$ Furthermore, the Ghanaian procurement system restricts the accessibility of information on evaluation outcomes explicitly to persons officially involved in the procurement procedure, and only upon request. ${ }^{33}$ Although this is indeed in line with international standards, ${ }^{34}$ it might be worth considering even more

\footnotetext{
${ }^{29} \mathrm{~S} 47$ PPA-G.

${ }^{30}$ S 56 (3) PPA-G; cf. Art 42 UNCITRAL Model Law on Public Procurement of 2011.

${ }^{31}$ S 31 PPA-G.

${ }^{32}$ Art xx UNCITRAL Model Law on Public Procurement of 2011.

${ }^{33} \mathrm{~S} 63$ PPA-G. Further issues resulting from this practice shall be part of the analysis of ch 4.2 .

${ }^{34}$ Art 25 (3) UNCITRAL Model Law on Public Procurement of 2011.
} 
transparency for the reasons mentioned above. The new Ugandan public procurement legislation, for instance, stipulates that besides the public display of best evaluated bidder, individual letters are to be sent to the bidders themselves. The notice contains information on the best evaluated bidder, notably the name, the proposed total contract price, and the score reached during evaluation; as well as information on the unsuccessful bidders and the stage where their offers failed or were eliminated. ${ }^{35}$ In addition, the new Ugandan legislation has established a debriefing mechanism where bidders can request reasons for success or failure on bids from the procuring entity. ${ }^{36}$

\section{$2.3 \quad$ Record keeping}

Record keeping in public procurement is crucial for anti-corruption as any ex post verification is based on the procurement file. As the World Bank has put it,

"[i]t is often not recognized, but it is very costly not to keep good procurement records. The costs are hidden in lack of transparency, improper applications of procedures, long search of documents when complaints arise, and rendering audits more difficult. Record keeping is not popular for many reasons but it is an important element of good fiduciary management. For useful control of procurement procedures and audits, and also to ensure adequate budget expenditure, good record keeping is essential." ${ }^{\text {"37 }}$

Although record keeping has always been considered an essential part of good administrative practice, it is a difficult task in developing countries that face special challenges: The information and communication technology infrastructure is not very reliable - particularly in remote areas - so that filing is often paper based. External conditions such as humid weather conditions or limited storage capacities impede proper paper filing. Electronic filing could help overcome these difficulties and enable procuring entities to comply with legal provisions on record keeping. Yet, corruption in public procurement will not appear in any files - it is inherent to illegal transactions to avoid any written evidence. Hence, a red flag for corruption is rather the lack of

\footnotetext{
${ }^{35}$ Reg 4 Public Procurement and Disposal of Public Assets Regulations (Contracts), 2014, Supplement No. 3.

${ }^{36}$ Reg 6 Public Procurement and Disposal of Public Assets Regulations (Contracts), 2014, Supplement No. 3.

${ }^{37}$ World Bank 2003 (Vol 1): 11.
} 
documentation. Regulatory bodies are thus faced with the complicated task of distinguishing between non-documentation due to incapacity and dishonest intentions.

S 28 PPA-G lists all documents to be included in the procurement file, with the exception of public notices of bidding opportunities, bidding documents and addenda, and final signed contract documents, addenda and amendments that should be part of the file as well. ${ }^{38}$ Reports on the Ghanaian procurement systems have assessed record keeping as poor, however. ${ }^{39}$ The Public Procurement Authority has reacted accordingly by issuing a record-keeping manual. ${ }^{40}$ In terms of transparency, it is well-defined by law, which information contained in the records should be made accessible to whom; e.g., anyone shall have access to information on the nature of the procurement and to names and addresses of bidders, including the winning bidder, but only participating bidders, i.e. those who have submitted an offer, have the right to information on qualifications, evaluation, rejection, cancellation, justification of procurement procedure, etc. ${ }^{41}$ Considering the fact that both audits, and requests for reviews initiated by bidders are based on procurement records, two main issues appear in this section. First, only those bidders who have actually submitted an offer or have passed the prequalification are right-holders to information on the tender procedure, whereas "[a]ny supplier, contractor or consultant that claims to have suffered, or that may suffer loss or injury due to a breach of a duty imposed on the procurement entity by this Act, may seek review ...." ${ }^{42}$ Those potential contractors that were unlawfully excluded from participating in the tender procedure, hence, have the right to claim a review, but not to obtain necessary information from the relevant procuring entity. Secondly, the "procurement entity is not liable to tenderers for damages owing solely to a failure to maintain a record of the procurement proceedings in accordance with this section." ${ }^{43}$ Consequently, claimants of a procurement procedure who are entitled to, but

\footnotetext{
${ }^{38}$ Cf. World Bank 2010: 61.

${ }^{39}$ World Bank 2003 (Vol 2): 18, 25; World Bank 2007: 9.

${ }^{40}$ As planned in the annual report 2011 of the Public Procurement Authority of Ghana 2012: 27-28.

${ }^{41}$ Ss 28 (2) and (3) PPA-G.

${ }^{42}$ S 78 (1) PPA-G. According to s 98 PPA-G, a "supplier or contractor" is defined as "any potential party or the party to a procurement contract with the procuring entity".

${ }^{43}$ S 28 (5) PPA-G.
} 
deprived of relevant information, are not legally protected. These two loopholes would urgently need to be remedied in the forthcoming revised PPA-G.

\subsection{Contract management}

Public procurement covers the whole process of contract formation. ${ }^{44}$ While procedures during the actual tendering phase - including advertisement, solicitation, opening, evaluation, and awarding - are densely regulated in the laws, pre- and postbidding phases such as needs assessment, budgetary planning, and contract management are often neglected by procurement legislation. However, these areas are not less vulnerable to corruption. Falsified or absent procurement planning opens the door to unnecessary and uncontrolled spending for the sole purpose of generating income in corruption; incorrect contract management facilitates excessive contract overpricing and poor contract performance such as low quality or delays in project execution. In any of these cases, corrupt agreements among procurement bodies and contractors will not manifest during the tender stage, but only after the contract has come into force.

Despite the fact that all phases of contract administration are explicitly included in the scope of application of the PPA-G, contract management is not prescribed in detail. ${ }^{45}$ The law states that terms and conditions, as well as the contract template are to be included in the tender solicitation documents. ${ }^{46}$ This informs both potential contract parties about the rules under which contract execution is supposed to take place. Furthermore and more directly linked to actual contract management, considerable price increases after contract signature shall be reported to, yet not be approved by the Tender Review Board in charge. ${ }^{47}$ Stipulations on contract amendments are not made. ${ }^{48}$ Yet interviewees - the African Development Bank in particular - have come to the conclusion that fraud in public procurement often takes place after the contract has been awarded. ${ }^{49}$ The World Bank has closely monitored performance in contract management since the 2003 Country Procurement

\footnotetext{
${ }^{44}$ Cf. Transparency International 2000: 17.

${ }^{45} \mathrm{~S} 14$ (1) (b) PPA-G; cf. Dagbanja 2013: 90, n 60.

${ }^{46} \mathrm{~S} 50$ (f) PPA-G.

${ }^{47}$ S 87 PPA-G.

${ }^{48}$ World Bank 2010: 67.

${ }^{49}$ It was mentioned during interviews that the ongoing "Ghana Institutional Support Program to Oversight and Private Sector Development Institutions " of the African Development Bank had identified contract management as one of the major problems in public administration
} 
Assessment Report that mentions delays ${ }^{50}$ and cost overruns ${ }^{51}$ as major issues, but also failure to achieve expected deliverables, legal complications due to noncompliance with contract conditions, and political pressure. ${ }^{52}$ Although not being able to base findings on statistical evidence, the World Bank, in its External Review of Public Financial Management of 2007, notes that payment delays persist, completion certificates are not systematically issued, and no significant improvements have been made since the last assessment. ${ }^{53}$ In response, the Public Procurement Authority has decided to issue particular guidelines on contract management; ${ }^{54}$ they are, however, not available online. It would be preferable to make these guidelines widely accessible.

\section{Enforcement mechanisms ${ }^{55}$}

The various public procurement components based on the principles of transparency and competition discussed above are necessary to enhance the visibility of bureaucratic procedures and to make them accessible and verifiable for internal and external control instruments, such as audits by oversight authorities, administrative and judicial review systems, and investigations. ${ }^{56}$ These monitoring tools are of utmost importance in procurement as the decisions of public officials are not submitted to democratic accountability mechanisms like elections. Instead, procuring entities are accountable the superordinate body within the executive, usually the Ministry of Finance, and ideally also to legislative power. ${ }^{57}$ The deterrent effect of oversight arises from the consciousness of the actors that procedures can be monitored ex-post by independent authorities; the parties under potential scrutiny are

\footnotetext{
${ }^{50}$ World Bank 2003 (Vol 1): 10.

51 "A review in 2002 of 132 works contracts which constitute an important part of public expenditure, indicated that some $84 \%$ incurred cost-overruns of up to $30 \%$ of the initial amount." (World Bank 2003 (Vol 1): 4)

${ }^{52}$ World Bank 2003 (Vol 2): 22.

${ }^{53}$ World Bank 2007: 9.

54 The Public Procurement Authority of Ghana 2012: 27.

${ }^{55}$ This section is based on the conference paper "Administrative review systems in public procurement and their potential for anti-corruption impact: Kenya, Uganda and Tanzania in a comparative perspective" presented by Annika Engelbert at the 6th Public Procurement Research Students Conference at the School of Law, University of Nottingham, on 28-29 April 2014. Whistleblowing is an additional monitoring tool which is, however, not prescribed by procurement law and will therefore not be discussed in this contribution.

${ }^{56}$ Gordon 2006: 429. For a detailed analysis of monitoring mechanisms in public procurement with special regard to corruption cf. Engelbert 2014.

${ }^{57}$ Through the parliamentary Public Accounts Committee.
} 
more reluctant to behave unlawfully. ${ }^{58}$ The two sets of preventive measures against corruption are thus complementary: Although wide competition, proper record keeping, and publication of tender information are not sufficient to curb corruption as they lack enforcement powers, they provide the basis of operation for monitoring bodies. These enforcement mechanisms shall be analyzed in the following.

\subsection{Compliance checks and audits}

Procurement activities of public entities are subject to multiple internal and external control mechanisms. Internal control consists of self-assessment tools, whereas external oversight authorities conduct special procurement compliance checks or general audits. One of the central tasks of national procurement regulatory authorities is to monitor compliance of individual procuring entities, but due to their limited investigatory powers, suspected corruption cases revealed during this procedure are referred to the anti-corruption agency in charge. ${ }^{59}$ As procurement is not the core function of public bodies, but rather a means to achieve its objectives, these bodies are also subject to common audit systems, e.g. the Auditor-General. Despite the complementary character of compliance checks and audits, they face a number of challenges with regard to fighting corruption: First, the coverage of compliance monitoring is limited as it is typically based on stratified sampling due to resource restrictions. They are primarily regarded as a tool to measure the overall rule-consistency of the procurement system, whereas the detection of corrupt activities is rather a 'byproduct'. A perfectly compliant system is not necessarily corruption-free; many of the most common ways to disguise corrupt agreements in procurement, e.g. customized specifications for only one preferred supplier, are extremely difficult to detect as they seem in conformity with the law. The same applies for audits, as long as they are not explicitly targeted at detecting wrongdoings in procurement, but rather take into account general good financial management. Second, monitoring bodies that operate in environments where corruption is systemic and endemic, cannot act fully independently. A lack of political will, as well as a lack of self-interest in fighting corruption in procurement from the authorities themselves can falsify audit outcomes. Procurement audits are hence

\footnotetext{
${ }^{58}$ Cf. Gordon 2006: 431; cf. Zhang 2007: 329.

${ }^{59}$ Anti-corruption agencies can take different institutional forms, cf. Hussmann et al 2009. See also ch 4.2 .
} 
suitable to monitor general compliance, but their reach remains superficial based on procurement records where corruption rarely manifests.

The Ghanaian procurement system provides for both internal and external control mechanisms: On the one hand, the Public Procurement Authority is mandated to conduct compliance checks within the procuring entities. ${ }^{60}$ While the procedure is randomized in East African procurement systems, all 1046 Ghanaian procuring entities are assessed by making use of the so-called Public Procurement Model of Excellence tool. ${ }^{61}$ This method is very comprehensive, but also very long and costly - it is rather unlikely that financing and staffing of the Public Procurement Authority will allow for continuous compliance checks of every single entity on an annual basis. The Public Procurement Authority is currently working on a supplementary selfassessment tool. On the other hand, according to the procurement legislation, external control instances, such as the Auditor-General, shall annually audit procurement activities of the entities. ${ }^{62}$ In 2007, the World Bank came to the conclusion that the Ghanaian audit system was not yet well developed as there was a lack of capacity to carry out specialized procurement audits. ${ }^{63}$ Yet the World Bank report of 2010 reveals considerable improvements, inter alia the establishment of a specialized procurement audit unit in the Office of the Auditor-General. ${ }^{64}$

\subsection{Review systems}

Compared to procurement audits, administrative and judicial review systems, i.e. the "legal mechanisms that allow suppliers to challenge public procurement decisions and to obtain relief where it can be shown that procurement rules were not adhered to" 65 have some crucial advantages in their capacity to curb corruption. In the first place, aggrieved bidders have the strongest interest in revealing corrupt activities: Unlawful decision making in procurement has an immediate economic effect on disadvantaged bidders, whereas auditing bodies do not get incentivized to ensure integrity. While being less objective in their evaluation of the procurement proceedings than external monitoring authorities, bidders are part of the procurement

\footnotetext{
${ }^{60} \mathrm{~S} 3(\mathrm{~d})$ and (e) PPA-G.

${ }^{61}$ The Public Procurement Authority of Ghana 2012: 5; in more detail World Bank 2010: 51.

${ }^{62}$ S 91 PPA-G.

${ }^{63}$ World Bank 2007: 12, 46, 60.

${ }^{64}$ World Bank 2010: 72, 76.

${ }^{65}$ Quinot 2013: 308.
} 
process and therefore have an advantage, both in terms of time and information. ${ }^{66}$ Based on their own experience, they can react instantly to deviations from the rule, whereas procurement records are the only source of knowledge for audits. The advantage of the review system is the role of the bidder as initiator of the process, with stronger incentives to report corruption and better access to information on corrupt activities than external actors. ${ }^{67}$ Furthermore, reviews are not concerned with the problem of fragmentary control, as every procurement procedure is potentially subject to challenge; bid challenge systems thus, reach - theoretically - maximum control coverage.

However, the control function of review systems can only unfold when bidders make use of the mechanism. Although the decision to lodge a review is dependent on the specific context and therewith not enforceable by external instances, the institutional framework can be designed in a way to encourage bidders to complain if necessary. In order to become effective, review systems need to fulfill two main criteria: independence from political influence and accessibility for complainants.

Review systems can vary between states in their exact form. Art 9 (1) (d) United Nations Convention against Corruption requires signatory states to set up at least a two-tier challenge system for public procurement, consisting of an administrative and a judicial review stage. Arts 64 (2) and 66 UNCITRAL Model Law on Public Procurement of 2011, on the other hand, cover a three-tier system, consisting of an (optional) application for reconsideration to the procuring entity, a request for review to the independent review body, and an appeal to court. In Ghana, requests for reviews are to be lodged with the head of the respective procurement entity in the first instance, ${ }^{68}$ and to the Public Procurement Authority in a second step. ${ }^{69}$ It is arguable whether reconsideration by the procuring entity is efficient or not; ${ }^{70}$ with regard to anti-corruption, a preliminary complaint stage will have only limited deterrence effects. Within the theoretical frame of a principal-agent-client relationship, the procuring entity (as the 'agent') is inevitably involved in corrupt activities - leaving instances of collusion aside - and has no incentives to investigate

\footnotetext{
${ }^{66}$ Cf. Zhang 2007: 330.

67 Arrowsmith 2003: 402.

68 S 79 PPA-G.

${ }^{69}$ Ss 80, 81 PPA-G; cf. Dagbanja 2013: 85.

70 Udeh 2013: 189; cf. Gordon 2006: 433.
} 
on corruption. There is, hence, a need for a controlling body outside the corrupt network. ${ }^{71}$

Independence and impartiality of administrative review bodies are crucial, particularly in environments where corruption in procurement is steered by political and economic elites, and where people tend to refrain from litigation. ${ }^{72}$ If bidders perceive review authorities as subordinates of corrupt political decision makers, they will not trust in their neutrality and consequently abstain from bringing up alleged corruption cases. However, the Ghanaian procurement system does not provide for an independent review authority. Although attempts were made in 2007 to create a fully autonomous and independent review body, ${ }^{73}$ these plans have been abandoned as confirmed in interviews. Instead, the Public Procurement Authority is in charge of carrying out administrative reviews ${ }^{74}$ and has created the ad hoc Appeals and Complaints Panel in 2007. ${ }^{75}$ The Ghanaian Public Procurement Authority assumes a double function: On the one hand, it is in charge of giving advice to procuring entity on general issues and also specific cases; on the other hand, it will review these same cases and may decide contrarily to its own initial recommendation. ${ }^{76}$ This conflicting mandate of the Public Procurement Authority is not uncommon in procurement systems in Sub-Saharan Africa. However, recent reform developments - e.g. in Uganda ${ }^{77}$ and Tanzania ${ }^{78}$ - have shown that administrative review systems increasingly become independent and less entangled in regulatory activities.

\footnotetext{
${ }^{71}$ Cf. Nicholas 2009: 157.

72 Cf. Quinot 2013: 313. Expert interviews with procurement authorities, review bodies and bidders as well as with external stakeholders in Ghana have revealed that judicial review remains an exception. ${ }_{73}^{73}$ World Bank 2007: 65.

${ }^{74} \mathrm{~S} 3(\mathrm{~m})$ PPA-G.

${ }^{75}$ World Bank 2007: 11, 46. Public information on the Appeals and Complaints Panel is scarce. According to the World Bank report 2010, the panel in 2007 consisted of 7 members (legal and procurement experts from the public and private sector, and three representatives of the Public Procurement Authority). The panel submits recommendations to the board of the Public Procurement Authority that takes the final decision. In 2009 and 2010, the panel was not operational for about one year. Guidelines on the administrative review process were drafted, but not formally put into place (World Bank 2010: 83, 86, 89).

${ }^{76}$ The World Bank also raises this concern for the double function of the Ghanaian Public Procurement Authority, cf. World Bank 2010: 28, 48.

${ }^{77}$ Similarly to the Ghanaian model, the former Ugandan Complaints Review Board was not a separately established body, but operated as an ad hoc committee of the procurement regulatory authority. The new procurement act of 2014 adds an independent appeals tribunal to the review system as a third instance following reviews by the procuring entity and the procurement regulatory authority. The tribunal is a quasi-judicial body mandated with powers similar to courts of law, including taking evidence on oath, ordering costs and summoning witnesses (s 91K PPA-U). The Ugandan
} 
Regarding the criterion of accessibility for bidders, two factors must be considered: provisions limiting the general openness of the review system and the actual use of the system, manifested in case numbers. Information on the latter is scattered for Ghana. Already in 2003 - before the current regulatory framework came into force the World Bank reported that only few disputes regarding procurement accrued mainly because bidders feared retaliation. These disputes were amicably solved. ${ }^{79}$ Case numbers between 2005 and 2011 seem to be between ten and fifteen annually, on average ${ }^{80}$ - a value that is, even compared to East African review systems, ${ }^{81}$ extremely low. In terms of transparency, it is striking that only a selected part of the review cases is published online. As confirmed by the Public Procurement Authority, this is intentionally done in order not to attract frivolous complaints - a practice that is highly questionable. Even though reliable data is not available, it can be concluded that the Ghanaian administrative review system is very poorly used, and that a general reluctance of bidders to make use of the system prevails. As the last stage of the procurement review system, judicial review is treated by the courts of justice, but not regulated in the procurement law. Not surprisingly, there are very few court decisions on procurement. ${ }^{82}$

Furthermore, the degree of accessibility of a review system is provided by law. Clauses can exempt grounds from being challengeable, as it is the case for decisions on the selection of a method of procurement and on tender rejection in Ghana. ${ }^{83}$ Although this used to be according to international standards until the revised UNCITRAL Model Law, it is not the case anymore and should be considered

\footnotetext{
administrative review system has hence developed from weak structures as integral parts of the procurement regulatory authority to a much elaborated three-tier mechanism with strong enforcement powers.

${ }^{78}$ In the previous Tanzanian public procurement act from 2003, the procurement regulatory authority had a double function acting both as oversight and review body. In some instances, the authority had given advice during the tender procedure, but when it came to an appeal on the very same topic, it had decided contrary to the previously made recommendations. This administrative review stage had therefore been removed from the text of the recently revised act.

${ }^{79}$ World Bank 2003 (Vol 2): 18, 28.

${ }^{80}$ December 2005 - April 2007: 21 cases (World Bank 2007: 11); February 2007 - May 2009: 31 cases (World Bank 2010: 37 and 87); in 2010, four cases were retrievable from the website (World Bank 2010: 88); 2011: ten cases (The Public Procurement Authority of Ghana 2012: 8); 2012: two cases published on the website; 2013: eight cases published on the website.

${ }^{81}$ In 2012, the Kenyan review board heard 73 cases, the Ugandan Complaints Review Board 18 cases and the Tanzanian administrative review system 22 cases.

82 Dagbanja 2013: 85.

${ }^{83}$ S 78 (1) PPA-G.
} 
for change in the current reform process. ${ }^{84}$ The incorrect choice of procurement method, as well as the rejection, particularly repeated rejection of all tenders can unlawfully exclude bidders by restricting participation. They should, hence, be given the right to challenge the procuring entity's decision. Secondly, bidders need to be given time to prepare for a review procedure. This is commonly materialized by standstill periods, i.e. a timeframe between the contract award notice and the contract signature so that decisions can potentially be rectified before the procurement project is executed. Ghanaian procurement law provides the Public Procurement Authority the opportunity to suspend the procurement procedure for a minimum of seven days, and a maximum of 30 days when a request for review is lodged..$^{85}$ It would be preferable, however, to introduce a mandatory standstill period to offer bidders sufficient legal protection. ${ }^{86}$ Last but not least, aggrieved bidders must have access to information concerning the tender procedure, as it enables them to judge whether or not the award decision has been taken on fair grounds. In Ghana, this information is only given to persons involved in the procurement procedure on request, ${ }^{87}$ which leads to two problems: Those unlawfully excluded from participating in tendering do not have the right to obtain information and are consequently de facto prevented from proper preparation of their cases. Secondly, information can be requested but might be delivered late so that the standstill period - if installed by the Public Procurement Authority - has lapsed and the contract is already executed. This issue does not only concern disadvantaged bidders, but also the Public Procurement Authority - although they are legally entitled to obtain any information on tender proceedings from the procurement entities. ${ }^{88}$ As reported by the World Bank: "Decisions are not all the time deliberated on the basis of available information. Missing information and time limits for issuing decisions impede/delay the complaints process. Some complaints were dismissed because the Appeals \& Complaints Panel (A\&C Panel) was not able to obtain information from the procuring entities." ${ }^{89}$

\footnotetext{
${ }^{84}$ Cf. World Bank 2010: 29.

${ }^{85}$ S 82 PPA-G.

${ }^{86}$ Cf. World Bank 2010: 84.

${ }^{87}$ S 63 PPA-G; see ch 2.2.

${ }^{88}$ S 88 PPA-G.

${ }^{89}$ World Bank 2010: 83.
} 
Incentives for bidders to complain, namely a realistic chance of winning the case and obtaining adequate compensation, are rather weak: The preparation of the complaint file is challenging as described above, success rates for claimants are low, ${ }^{90}$ and available remedies cover "payment of compensation for reasonable costs incurred ... in connection with the procurement proceedings..."91. The Appeals and Complaints Panel can, however, neither annul a procurement contract once it has entered into force $^{92}$ nor order liquidated damages, which makes a review procedure less attractive for bidders.

In summary, the potential of the Ghanaian procurement review system to serve as an effective anti-corruption tool is, by far, not yet realized. There is still much room for improvement ${ }^{93}$ - nevertheless it seems to be a political decision not to strengthen independence of the review body and accessibility for the bidders in the future. Given the positive aspects for curbing corruption discussed above, this would be a very unfortunate development and calls for reconsideration.

\section{Scope and limitations in sanctioning corruption in public procurement}

As discussed above, certain elements of public procurement systems are very useful in revealing corrupt activities. However, jurisdiction under administrative law is limited to irregularities in the procurement process in terms of deviations from the rules. Regulatory procurement authorities are mandated to conduct investigations and impose sanctions related to procurement contract matters only, whereas criminal offences need to be referred to the law enforcement organs of the state where they are investigated and prosecuted. The deterrent effect of administrative sanctions, i.e. the potential punishment, is weaker than threatening criminal proceedings that may result in litigation and conviction. Both components, namely sanctioning according to public procurement law, and collaboration between the procurement system and the prosecution service, shall be discussed in the following.

\footnotetext{
${ }^{90}$ None of the eleven administrative review cases concluded in the Financial Year 2011/12 was decided in favor of the claimant. Cf. The Public Procurement Authority of Ghana 2012: 51-57.

${ }^{91} \mathrm{~S} 80$ (3) (f) PPA-G.

${ }^{92} \mathrm{~S} 80$ (3) (d) and (e) PPA-G.

${ }^{93}$ Cf. World Bank 2010: 73.
} 


\subsection{Sanctions}

The public procurement system can punish corrupt activities of bidders and procurement officers by debarment from future tender opportunities, exclusion from professional cadres, and fines. These administrative sanctions have a certain deterrent effect as they have the capacity to ultimately disrupt the corrupt business relationship between bidders and procurement officers: Debarment means a temporary suspension of a corrupt company from any public tender participation, while public officers can be dismissed from their current position or from public service as a whole. Both parties can be subjected to a fine prescribed by law, and also face liability for damages. Depending on their actual value, these fines can have a serious economic impact on companies and also on individuals.

Corruption as an offence is not mentioned explicitly in the PPA-G, except for s 93 (2) that refers to the definition of corruption as stated in the Criminal Code, 1960 (Act 29). However, unlawful behaviour commonly regarded as corrupt is described in the Act. S 32 states that

"[a] procurement entity shall reject a tender, proposal, offer or quotation if the supplier, contractor or consultant that submitted it offers, gives or agrees to give, directly or indirectly, to any current or former officer or employee of the procurement entity or other governmental authority,

(a) a gratuity in any form;

(b) an offer of employment; or

(c) any other thing of service or value

as an inducement with respect to anything connected with a procurement entity and procurement proceedings."

The provision is, however, unidirectional and toothless, as it targets only one part of the corrupt relationship - the bidder -, and does not stipulate any sanction except the rejection of a bid. There is no escalation strategy prescribed, which means in return that the attempt to offer a bribe or something similar remains exempt from 
punishment. S 92 seems to be more relevant as it defines the following corrupt activities as 'offences':

"(a) entering or attempting to enter into a collusive agreement, whether enforceable or not, with any other supplier or contractor where the prices quoted in their respective tenders, proposals or quotations are or would be higher than would have been the case has there not been collusion between the persons concerned;

(b) directly or indirectly influencing in any manner or attempting to influence in any manner the procurement process to obtain an unfair advantage in the award of a procurement contract;

(c) altering any procurement document with intent to influence the outcome of a tender proceeding and this includes but is not limited to

(i) forged arithmetical correction;

(ii) insertion of documents such as bid security or tax clearance certificate which were not submitted at bid opening; and

(d) request for clarification in a manner not permitted under this Act."

A person guilty of an offence is liable, upon conviction by a court of law, to a fine, imprisonment or both. PPA-G states potential penalties. ${ }^{95}$ Nevertheless, the Public Procurement Authority itself is not mandated to impose sentences except for remedies such as such as, inter alia, annulment of the procurement proceedings or cancellation of the procurement contract. ${ }^{96}$ For matters related to procurement procedures, the authority is vested with investigatory powers of entry and search. ${ }^{97}$

Furthermore, the Ghanaian Public Procurement Authority is mandated to exclude suppliers and service providers from procurement practice; ${ }^{98}$ however, the debarment procedure has not yet been implemented. ${ }^{99}$ The reason given in

\footnotetext{
${ }^{94}$ S 92 (2) PPA-G.

${ }^{95} \mathrm{~S} 92$ (1) PPA-G.

${ }^{96} \mathrm{~S} 90$ (2) PPA-G.

${ }^{97}$ S 89 PPA-G.

$98 \mathrm{~S} 3(\mathrm{q})$ and $(\mathrm{r}) \mathrm{PPA}-\mathrm{G}$.

${ }^{99}$ Cf. World Bank 2010: 22.
} 
interviews was that bidders should not be discouraged from participation, as competition has not yet attained a satisfactory level. The same argument was made in Kenya, where debarment procedures are - consciously - not implemented. Apart from referring to Art 284 of the Ghanaian constitution that requires public officers not to get involved in a situation of conflict of interest, PPA-G remains silent on consequences for procurement officials engaged in corrupt practices. Thus, the legal framework does not make full use of its actual capacities of sanctioning corruption. It is hence even more important to involve law enforcement agencies in the fight against corruption in procurement.

\subsection{Collaboration with law enforcement bodies}

The relatively weak deterrent effect of administrative sanctions needs to be compensated by strong criminal law enforcement. The collaboration between public procurement authorities and prosecution bodies, i.e. anti-corruption agencies, public prosecution, the police or others, is of crucial importance. Where the exposure of corruption does not lead automatically to criminal investigation and potential prosecution and conviction, the credibility of the anti-corruption function of the procurement system is diluted. If there is no perceptible risk of conviction, the deterrent effect is further undermined. Additionally, the jurisdiction of criminal law encompasses, in contrast to public procurement law, both bureaucratic and political corruption. In systems where corruption is endemic, politicians are regularly involved in distorting public procurement procedures towards their own personal benefits. Again, only independent and powerful prosecution services and courts have the capacity to punish high-level corruption in public procurement.

The World Bank's assessment report of the Ghanaian public procurement system of 2010 provides a detailed analysis of the interplay between the procurement regulatory authority and law enforcement organs. As it is the case in many common law countries in Sub-Saharan Africa, Auditor General's reports are submitted to the parliamentary Public Accounts Committee that can issue recommendations. In Ghana, a Financial Administration Tribunal had been created with jurisdiction to enforce these recommendations, and whose orders are enforceable in the same manner as orders of the High Court. At the time the report was drafted, the tribunal 
was not operational yet ${ }^{100}$ - and seems not to be until to date according to information available online. ${ }^{101}$

The Ghanaian Commission on Human Rights and Administrative Justice (CHRAJ) was complemented in 2009 by a specialized anti-corruption division that is mandated to investigate alleged corruption cases, inter alia complaints on violations of public officers' Code of Conduct or conflict of interest issues. ${ }^{102}$ Despite the World Bank's assessment that "[s]uch cooperation could help establish confidence in the public procurement system, notably in the complaints and appeals mechanisms"103, a formalized cooperation structure between the Public Procurement Authority and CHRAJ is still pending.

\section{Conclusion}

The World Bank in 2003 gave a rather disappointing picture of fighting public procurement corruption in Ghana: investigation of procurement related corruption was poor, corruption in the public service was generally perceived to be widespread, efforts of the public sector to create awareness of anti-corruption measures were insufficient, the Civil Service Code was not enforced, and the Audit Service was restricted in reporting adequately on alleged fraud and corruption cases. ${ }^{104}$ The introduction of a sound regulatory framework has implemented a number of preventive measures that have the capacity to form a strong anti-corruption mechanism. This study has identified potential improvements that could be made to consolidate these elements within the revised public procurement act:

- Open tendering should become the main procurement method used, inter alia via adaptation of the current thresholds, to enhance competition. The choice of the procurement method should become challengeable to avoid abuse of restrictive tendering (see section 2.1).

- Accessibility of tender information should be facilitated for bidders, overseeing authorities and the general public (see sections 2.2 and 2.3).

\footnotetext{
${ }^{100}$ World Bank 2010: 92.

${ }^{101}$ Citifmonline 17.10.2014.

102 World Bank 2010: 72, 92.

${ }_{103}$ World Bank 2010: 93.

${ }^{104}$ World Bank 2003 (Vol 2): 90.
} 
- Contract management needs to be integrated into the public procurement law (see section 2.4).

- Audit institutions need to lay a special focus and hence to be properly trained on procurement issues (see section 3.1).

- The administrative review system must be strengthened by creating an independent adjudication body, by opening up the possibility to challenge decisions to a wider range of right-bearers and by providing sufficient time and information to those who wish to lodge a complaint (see section 3.2).

- Collaboration between the Public Procurement Authority and law enforcement organs, in particular the CHARJ, needs to be formalized, in order to make procurement-related corruption a risky business (see section 4.2).

Considering the fact that the substance of any legislation aiming to reduce corruption - also via preventive rather than penal measures - as well as its translation into anticorruption policies and the enforcement of the latter, is ultimately subject to the political will of those who often take the most advantage of this corrupt system. The current legislative reform process could be regarded as an indicator for the actual willingness of political decision makers to curb corruption. At least, from what is known for the future development of the administrative review system, influence peddling from the political class is very strong and will strive for persistence instead of granting autonomy to external monitoring bodies. 


\section{Bibliography}

Akech, J.M. 2006. Development Partners and Governance of Public Procurement in Kenya: Enhancing Democracy in the Administration of Aid. NYU Journal of International Law and Politics 37 (4): 829-868.

Aidt, Toke S. 2011. Corruption and sustainable development. In Rose-Ackerman, S. \& Søreide, T. (Eds.). International handbook on the economics of corruption. Cheltenham, Northampton, MA: Edward Elgar.

Andvig, J. C. et al. 2000. Research on corruption: A policy oriented survey. Bergen: Chr. Michelsen Institute.

Arrowsmith, S. 2003. Government Procurement in the WTO. The Hague: Kluwer Law International.

Bayley, David H. 1989. The Effects of Corruption in a Developing Nation. In Heidenheimer, A. J., Johnston, M. \& Le Vine, V. T. (Eds.). Political corruption. $A$ handbook. New Brunswick: Transaction Publishers.

Dagbanja, D. N. 2013. The regulatory framework for public procurement in Ghana. In Quinot, G. \& Arrowsmith, S. (Eds.). Public procurement regulation in Africa. Cambridge: Cambridge University Press.

Engelbert, A. 2014. Administrative review systems in public procurement and their potential for anti-corruption impact: Kenya, Uganda and Tanzania in a comparative perspective. Conference paper presented at the 6th Public Procurement Research Students Conference at the School of Law, University of Nottingham, on 28-29 April 2014, available on http://www.nottingham.ac.uk/pprg/conferencesandevents/research-studentsconference.aspx (accessed March 27, 2015).

Gordon, D. I. 2006. Constructing a bid protest process: The choices that every procurement challenge system must make. Public Contract Law Journal 35 (3): 427-445. 
Heggstad, K. K. \& Frøystad, M. 2011. The basics of integrity in procurement. U4 Issue, 10. Bergen: Chr. Michelsen Institute.

Hussmann, K., Hechler, H. \& Peñailillo, M. 2009. Institutional arrangements for corruption prevention: Considerations for the implementation of the United Nations Convention against Corruption Article 6. U4 Issue 4. Bergen: Chr. Michelsen Institute.

Khan, M. H. 2006. Determinants of corruption in developing countries: the limits of conventional economic analysis. In Rose-Ackerman, S. (Ed.). International handbook on the economics of corruption. Cheltenham, Northampton, MA: Edward Elgar.

Lambsdorff, J. Graf. 2006. Causes and consequences of corruption: What do we know from a cross-section of countries? In Rose-Ackerman, S. (Ed.). International handbook on the economics of corruption. Cheltenham, Northampton, MA: Edward Elgar.

Mauro, P. \& Driscoll, D. D. 1997. Why worry about corruption? Economic issues, 6. Waschington, D.C.: International Monetary Fund.

Moody-Stuart, G. 1997. Grand corruption. How business bribes damage developing countries. Oxford: WorldView.

Nicholas, C. 2009. Remedies for breaches of procurement rules and the UNCITRAL Model Law on Procurement. Public Procurement Law Journal 18 (4): 151159.

Ofosu-Amaah, W. P., Soopramanien, R. \& Uprety, K. 1999. Combating corruption. A comparative review of selected legal aspects of state practices and major international initiatives. Washington, D.C.: World Bank.

Piga, G. 2011. A fighting chance against corruption in public procurement? In RoseAckerman, S. \& Søreide, T. (Eds.). International handbook on the economics of corruption. Cheltenham, Northampton, MA: Edward Elgar. 
Quinot, G. 2013. A Comparative Perspective on Supplier Remedies in African Public Procurement Systems. In Quinot, G. \& Arrowsmith, S. (Eds.). Public procurement regulation in Africa. Cambridge: Cambridge University Press.

Søreide, T. 2002. Corruption in public procurement. Causes, consequences and cures. CMI Report, 1. Bergen: Chr. Michelsen Institute.

Szeftel, M. 2000. Clientelism, corruption \& catastrophe. In Review of African Political Economy 27 (85): 427-441.

Transparency International. 2006. Handbook for Curbing Corruption in Public Procurement. Berlin: Transparency International.

Transparency International. 2000. Sourcebook. Chapter 22: Public Procurement. Berlin: Transparency International.

Udeh, K. T. 2013. A critical appraisal of Kenya's supplier review system in the light of international standards. Public Procurement Law Review 22 (5): 183-203.

Ware, G. T. et al. 2011. Corruption in procurement. In Graycar, A. \& Smith, R. G. (Eds.): Handbook of global research and practice in corruption. Cheltenham, Northampton, MA: Edward Elgar.

Williams-Elegbe, S. 2012. Fighting Corruption in Public Procurement. Portland: Hart Publishing.

Zhang, X. 2007. Supplier review as a mechanism for securing compliance with government public procurement rules: A critical perspective. Public Procurement Law Review 16 (5): 325-351.

\section{Legislation}

Busan Partnership for Effective Development Co-operation of 2011

Reprint of the Public Procurement and Disposal of Assets Act, No. 1 of 2003 (Uganda) 
The Public Procurement and Disposal of Public Assets Regulations (Contracts), 2014, Supplement No. 3 (Uganda)

The Public Procurement Act (Act 663) of 2003 (Ghana)

UNCITRAL Model Law on Procurement of Goods, Construction and Services of 1994

UNCITRAL Model Law on Public Procurement of 2011

United Nations Convention against Corruption of 2003

\section{Internet sources}

Bank of Ghana. 2015. National CPI and inflation rates. Available at $<$ http://www.bog.gov.gh/index.php?option=com wrapper\&view=wrapper\&ltem $\underline{\mathrm{id}=263>}$ [Accessed 27 March 2015].

Citifmonline. 17.10.2014. Financial tribunals record zero cases - Judicial Service. Available at: <http://www.citifmonline.com/2014/10/17/financial-tribunalsrecord-zero-cases-judicial-service/\#sthash.oM1Ne9mE.dpbs> [Accessed 27 March 2015].

The Public Procurement Authority of Ghana. 2012. 2011 Annual Report. Available at: <http://www.ppaghana.org/ppapage.asp?Category=13\&SubCategory=31> [Accessed 27 March 2015].

The World Bank. 2013. Worldwide Governance Indicators. Available at: http://info.worldbank.org/governance/wgi/index.aspx\#home> [Accessed 27 March 2015].

The World Bank. 2010. Ghana - Assessment of Stage 1, Use of Country Procurement Systems in Bank-Supported Operations: Proposed Piloting Program (27.08.2010). Available at: $<$ http://documents.worldbank.org/curated/en/2010/08/16597182/ghana- 
assessment-stage-one-use-country-procurement-systems-bank-supportedoperations-piloting-program> [Accessed 27 March 2015].

The World Bank. 2008. Ghana 2007 External Review of Public Financial Management, Volume II: Public Procurement Assessment Report (June 2008). Available at:

$<$ http://documents.worldbank.org/curated/en/2008/06/9727354/ghana-2007external-review-public-financial-management-vol-2-2-public-procurementassessment-report> [Accessed 27 March 2015].

The World Bank. 2003. Ghana Country Procurement Assessment Report 2003 (Vol 1). Available at:

$<$ http://documents.worldbank.org/curated/en/2003/06/3582647/ghana-countryprocurement-assessment-report-vol-1-5-executive-summary $>$ [Accessed 27 March 2015].

The World Bank. 2003. Ghana Country Procurement Assessment Report 2003 (Vol 2). Available at:

<http://documents.worldbank.org/curated/en/2003/06/3582670/ghana-countryprocurement-assessment-report-vol-2-5-main-report> [Accessed 27 March 2015].

Transparency International. 2014. Corruption Perceptions Index, 2014. Available at: <http://www.transparency.org/cpi2014/results > [Accessed 27 March 2015]. 